\title{
Effects of a beta-adrenergic receptor blocker in myocardial infarction treated for one year from onset
}

\author{
J. L. Reynolds and R. M. L. Whitlock \\ From the Departments of Medicine and Clinical Physiology, \\ Green Lane Hospital, Auckland, New Zealand
}

In a double-blind trial alprenolol $100 \mathrm{mg}$ four times daily or placebo was given to 87 patients for one year from onset of their acute myocardial infarction. Patients were assessed on five occasions after their discharge from hospital. The mortality and hospital readmission rates were not significantly different in the two groups. This also applied to the incidence of cardiac failure, exertional dyspnoea, and frequency of ventricular ectopic beats. The incidence of angina pectoris and the consumption of trinitrin were also not significantly different. The patients taking alprenolol had a significantly better rehabilitation rate judged by return to work. No injurious effect of alprenolol on the myocardium was observed using heart volume measurements as a criterion. There was a significant fall in resting systolic blood pressure between three months and one year in the patients on alprenolol and the systolic blood pressure during exercise on alprenolol was also significantly lower. Most patients felt better when exercised while taking alprenolol but there was no significant difference in the frequency of angina or ischaemic changes in the electrocardiogram during exercise with or without alprenolol. Ventilation and $\mathrm{O}_{2}$ uptake at rest and during exercise were lower on alprenolol. No bronchoconstrictor effect from alprenolol was detected.

Drugs capable of blocking the activity of the beta adrenergic receptors and having antiarrhythmic properties have been in use in the management of ischaemic heart disease for about six years, but the therapeutic indications and benefits to be derived have yet to be finalized. Further investigation is also needed to determine whether deleterious effects occur from long-term therapy. Snow (1965) reported a significant reduction in mortality in acute myocardial infarction treated with propranolol. Norris, Caughey, and Scott (1968) reported a double blind trial on 454 patients with acute myocardial infarction treated with propranolol or placebo and found no difference in mortality or clinical course between treated and control groups. These trials dealt only with the period of inpatient management. Of patients who suffer a myocardial infarction, 20-60 per cent subsequently develop angina pectoris (Yater $e t$ al., 1948; Gertler et al., 1951). Several workers (Gillam and Prichard, 1965; Wolfson et al., 1966; Hickie et al., 1970) have reported symptomatic improvement in patients with angina pectoris treated with a beta blocker. It has also been shown that sudden death

Received 17 May 1971. after myocardial infarction is more common in patients who had a serious ventricular arrhythmia during their stay in hospital (Denborough et al., 1968) and that sudden death is more common in subjects who have ventricular premature beats (Weiss et al., 1969). To assess the effects of beta adrenergic receptor blockade on these aspects a doubleblind trial was undertaken using the drug alprenolol (Aptin). A one-year follow-up was carried out to determine whether the pharmacological properties of alprenolol (Ablad, Brogard, and $\mathrm{Ek}$, 1967) would affect the symptomatic course or objective findings in patients with ischaemic heart disease.

The trial was arranged in two parts, the first assessing the effects on mortality, recurrent chest pain, and incidence of serious ventricular arrhythmias during the patient's stay in the coronary care unit (Briant and Norris, 1970). No significant difference in mortality or incidence of serious ventricular arrhythmia was found in this period between the patients on treatment and those on placebo.

\section{Methods}

It is our practice to admit directly to the Coronary Care Unit any patient under the age of 70 who 
has chest pain suspicious of myocardial infarction. Directly after admission, treatment was started taking tablets from the bottle next in order numerically. These had been prepared in random order by the hospital pharmacist who retained the key. Any patient who later did not have the diagnosis of myocardial infarction proven by the usually accepted criteria was withdrawn from the trial. Patients were also excluded if contraindications to $\beta$-blockade were present. These are heart block, systolic blood pressure of less than 90 for one hour, pulmonary oedema, sinus bradycardia of less than 50 beats per minute, and bronchial asthma.

Clinical follow-up Of the IIg patients in the first part of the trial, 9 died, ro were withdrawn because of complications, and 13 were excluded because diagnostic criteria were not fully met; 87 continued into the second part of the trial, and to receive alprenolol roo $\mathrm{mg}$ or placebo six-hourly while in hospital and after discharge when supplies of tablets were dispensed at six-weekly intervals by the hospital pharmacy. This was considered a satisfactory surveillance of the patients' compliance with the trial, as failure to take the tablets regularly would result in a delayed visit to the pharmacy. This did not happen with any of the patients who completed the trial. After discharge from hospital the patients were seen by

- the same observer at 6 weeks, and at 3,6, 9, and 12 months. At these times they were examined and the following additional data were obtained: electrocardiogram, heart volume, serum cholesterol, fatty acid esters, and haematocrit. Heart volume was determined from posteroanterior and left lateral chest films using formula $\mathrm{L} \times \mathrm{B} \times \mathrm{D} \times$ 0.45 , as described by Cooley and Schreiber (1967).

- Of the 87 patients discharged from hospital, 3 would not participate and 6 failed to keep appointments leaving 78 trial patients.

Exercise study A group of 30 patients (15 on treatment and 15 on placebo) was given two exercise tests. The first of these tests (with two exceptions in each group) was made on 'normal' treatment and the second was made after stopping 'normal' treatment for at least 18 hours and taking

- the alternative tablets two hours before the study. The two exceptions in each group had their studies in the reverse order.

The study consisted of a 3-minute rest period followed by treadmill walking at $2.5 \mathrm{~m}$.p.h. for a total of 12 minutes and then a 5-minute recovery period. The exercise was performed at three gradients: 3 minutes at 4 per cent, 3 minutes at 8

- per cent, and 6 minutes at 16 per cent. All but 4 patients ( 2 from each group) completed the full exercise programme: 2 of these could not complete the highest level on treatment or control tablets, I completed it only on treatment, and the fourth only on control tablets.

The electrocardiogram was monitored throughout the study and the instantaneous rate and - minute-by-minute count recorded by a cardiotachometer and heart beat counter (Philips). The expired air was passed through an 8-litre mixing chamber to a gas meter (Parkinson and Cowan C.D.4) arranged to give a signal at each litre. The expired air was analysed by side-arm sampling after the mixing chamber. The oxygen concentration was measured with a paramagnetic oxygenanalyser (Servomex controls) and the carbon dioxide concentration with a katapherometer (Godart), both instruments being connected to a digital voltmeter (Hewlett-Packard) from which readings were taken each minute. Respiratory frequency was measured by a pneumotachograph (Mercury Electronics). The respiratory frequency, minute volume in litres, and the instantaneous heart rate were recorded on an ultraviolet recorder (S.E. Laboratories). Electrocardiogram tracings and blood pressure measurements were taken at regular intervals throughout the study.

Calculations The oxygen uptake and RQ were calculated for each minute of the study. The averages were taken of the 3-minute rest period, the last 2 minutes at 4 and 8 per cent and the last 3 minutes at 16 per cent. It is probable that a steady state had not been reached at the lower levels but certainly would have been at the highest level. Because of a weight discrepancy between the groups (control group mean $74.7 \mathrm{~kg}$, treatment group $70.6 \mathrm{~kg}$ ) and a big variation of weight within the groups (Table 4) a correction was made for ventilation and oxygen uptake to a standard weight of $65 \mathrm{~kg}$. To make this correction at rest was considered misleading because the patients varied widely in obesity. In grade walking however the external work is closely related to the total body weight, and it was thought reasonable to make this correction for the exercise measurements, leaving the resting values uncorrected.

Statistical analysis The results from the year's trial were treated in two ways. Variables such as heart rate and serum cholesterol were compared within each of the control and treatment groups by a paired $t$ test to detect any changes over the course of the year. The two groups were also compared with each other in unpaired $t$ tests. The incidence of angina, readmissions, etc. was compared by means of a $\chi^{2}$ contingency test.

The results of the exercise studies were compared by means of $t$ tests. The whole group of 30 patients was compared on and off treatment using paired $t$ tests. The subgroups of 15 patients were compared using paired $t$ tests within the group or unpaired $t$ tests when comparing the control and treatment subgroups. $F$ tests were done on all the variables compared with $t$ test, and no inferences were drawn if the $F$ test showed a $P<0.05$.

\section{Results}

Clinical follow-up Seven patients were withdrawn from the trial and 18 had readmissions (Table I). These patients showed a similar incidence of heart failure and no significant difference in the readmission rate, between those on alprenolol and those on 
TABLE I

\begin{tabular}{|c|c|c|c|c|}
\hline & $\begin{array}{l}\text { Trial } \\
\text { No. }\end{array}$ & Alprenolol group & $\begin{array}{l}\text { Trial } \\
\text { No. }\end{array}$ & Placebo group \\
\hline \multirow[t]{4}{*}{ Withdrawn from trial } & I 57 & Drug inadvertently stopped & I7I & $\begin{array}{l}\text { Frequent anginal pain } \\
\text { (improved with alprenolol) }\end{array}$ \\
\hline & 52 & Developed cardiac failure & & \\
\hline & 44 & Developed pulmonary oedema & 126 & $\begin{array}{l}\text { Frequent anginal pain } \\
\text { (improved with alprenolol) }\end{array}$ \\
\hline & 108 & Drug inadvertently stopped & 104 & $\begin{array}{l}\text { Persistent sinus tachycardia } \\
\text { (controlled with alprenolol) }\end{array}$ \\
\hline \multirow{10}{*}{$\begin{array}{l}\text { Readmissions for ischaemic } \\
\text { heart disease }\end{array}$} & II9 & Acute myocardial infarction & 14 & Acute myocardial infarction \\
\hline & 52 & Cardiac failure & 128 & Coronary insufficiency \\
\hline & 157 & Acute myocardial infarction, & 126 & Acute myocardial infarction \\
\hline & 44 & LV failure & 7 & $\begin{array}{l}\text { Frequent angina, Takayasu's } \\
\text { disease }\end{array}$ \\
\hline & 155 & $\begin{array}{l}\text { Frequent angina, cardiac } \\
\text { neurosis }\end{array}$ & 103 & Acute myocardial infarction \\
\hline & 92 & Acute myocardial infarction & $6 I$ & Cardiac failure \\
\hline & 19 & Coronary insufficiency & 56 & Cardiac failure \\
\hline & 108 & Acute myocardial infarction & 163 & Acute myocardial infarction \\
\hline & & & 140 & Coronary insufficiency \\
\hline & & & $3 I$ & Cardiac failure \\
\hline \multirow[t]{3}{*}{ Deaths } & 152 & $\begin{array}{l}\text { Sudden, } 4 \text { wk after hospital } \\
\text { discharge; multiple ventric. } \\
\text { prem. beats in CCU }\end{array}$ & 14 & $\begin{array}{l}\text { Acute myocardial infarction, } \\
\text { shock }\end{array}$ \\
\hline & $2 \mathbf{I}$ & $\begin{array}{l}\text { Sudden, } 6 \text { mth after discharge; } \\
\text { no serious arrhythmia in } \\
\text { CCU }\end{array}$ & 103 & $\begin{array}{l}\text { Acute myocardial infarction, } \\
\text { multiple ventric. prem. } \\
\text { beats } \rightarrow \text { ventric. fibrill. }\end{array}$ \\
\hline & 92 & $\begin{array}{l}\text { Acute myocardial infarction; } \\
\text { died suddenly in asystole } \\
2 \text { wk after readmission }\end{array}$ & I6I & $\begin{array}{l}\text { Sudden, } 6 \text { mth after discharge; } \\
\text { multiple ventric. prem. } \\
\text { beats while in CCU }\end{array}$ \\
\hline
\end{tabular}

CCU: Coronary Care Unit.

placebo. These results were not influenced by the patient's history before inclusion in the trial as the incidence of previous myocardial infarction and angina pectoris in the treatment and placebo groups is not significantly different (Table 2).

Six patients died (Table I), 3 on alprenolol and 3 on placebo. An acute coronary event was responsible in all.

Angina pectoris (Table 2) At 3 months this was present in 59 per cent of patients on alprenolol and 47 per cent of those on placebo (difference not statistically significant). At I year the incidence was 53 per cent on treatment and 32 per cent on placebo. These differences were not statistically significant, and it is noteworthy that the two patients withdrawn from the trial because of severe angina of effort were found to have been on placebo. The symptoms of both improved appreciably when they were later given alprenolol.

Trinitrin consumption (Table 2) At 3 months 20.5 per cent on treatment and 18 per cent on placebo took trinitrin (no significant difference). At I year the incidence was 14.7 per cent in both groups.
Blood pressure The mean systolic blood pressure at 3 months and I year was not significantly different in the patients on alprenolol from those on placebo (Table 3). However, there was a significant drop in systolic blood pressure between 3 months and $I$ year in the patients taking alprenolol $(P<0.005)$.

TABLE 2 Clinical details on trial patients

\begin{tabular}{|c|c|c|c|}
\hline & Time & $\begin{array}{l}\text { Alprenolol } \\
\text { group }\end{array}$ & $\begin{array}{l}\text { Placebo } \\
\text { group }\end{array}$ \\
\hline $\begin{array}{l}\text { Incidence of previous myocardial infarction } \\
\text { Incidence of previous angina pectoris }\end{array}$ & 二 & $\begin{array}{l}20 \cdot 0 \% \\
36.0 \%\end{array}$ & $\begin{array}{l}31 \cdot 6 \% \\
36 \cdot 8 \%\end{array}$ \\
\hline Incidence of angina pectoris during trial & $\left\{\begin{array}{l}3 \text { mth } \\
\text { I yr }\end{array}\right.$ & $\begin{array}{l}59 \cdot 0 \% \\
53 \%\end{array}$ & $47.0 \%$ \\
\hline Patients taking trinitrin & $3 \mathrm{mth}$ & $20.5 \%$ & $18 \%$ \\
\hline & I yr & $14.7 \%$ & $14.7 \%$ \\
\hline Average trinitrin consumption (tablets/wk) & $\begin{array}{l}3 \text { mth } \\
\text { I yr }\end{array}$ & $\begin{array}{l}60 \\
37\end{array}$ & $\begin{array}{l}91 \\
76\end{array}$ \\
\hline Incidence of exertional dyspnoea during & $3 \mathrm{mth}$ & $12 \cdot 9 \%$ & $13.1 \%$ \\
\hline $\begin{array}{l}\text { trial } \\
\text { Back at normal occupation }\end{array}$ & $\begin{array}{l}\text { I } \mathrm{yr} \\
3 \mathrm{mth} \\
\text { I } \mathrm{yr}\end{array}$ & $\begin{array}{l}6 \% \\
58 \cdot 8 \% \\
81 \cdot 3 \%\end{array}$ & $\begin{array}{l}11 \cdot 7 \% \\
40 \cdot 6 \% \\
83 \cdot 9 \%\end{array}$ \\
\hline Back on light duties & $\left\{\begin{array}{l}3 \text { mth } \\
1 \mathrm{yr}\end{array}\right.$ & $\begin{array}{l}26.5 \% \\
15.6 \%\end{array}$ & $37.5 \%$ \\
\hline Not working & $\left\{\begin{array}{l}3 \mathrm{mth} \\
\mathrm{I} \mathrm{yr}\end{array}\right.$ & $\begin{array}{r}14.7 \% \\
3.1 \%\end{array}$ & $\begin{aligned} 21 \cdot 9 \% \\
6 \cdot 4 \%\end{aligned}$ \\
\hline
\end{tabular}


Ventricular premature beats Incidence was determined from the resting electrocardiogram and the period of auscultation. Premature beats occurred in 4 patients taking alprenolol and 3 taking placebo.

Exertional dyspnoea (Table 2) The incidence was similar in patients on alprenolol and placebo.

Return to work (Table 2) At 3 months there was a significantly better $(P<0.05)$ rehabilitation of the alprenolol group, but the difference

- was not so significant at I year.

Resting heart rate (Table 3) This was significantly lower in the patients taking alprenolol $(\mathrm{P}<0.00 \mathrm{I}$ at 3 months, $\mathrm{P}<0.00 \mathrm{I}$ at $\mathrm{I}$ year), compared with those on placebo.

- Heart volume (Table 3 ) The mean volumes at 3 months and I year for patients on alprenolol and placebo were within the normal range described by Domenet, Evans, and Howarth (1963). There was no significant difference between the two groups and no significant change between 3 months and $I$ year in - patients on alprenolol or placebo.

Body weight (Table 3) There was no significant difference between the alprenolol and placebo groups at 3 months or I year, but there was a significant fall in weight in patients on alprenolol between 3 months and $I$ - year $(\mathbf{P}<0.05)$.

Serum cholesterol (Table 3) There was no significant difference between placebo and alprenolol groups at 3 months or I year, but there was a significant fall in serum cholesterol in patients taking alprenolol between 3 months and $I$ year $(P<0.00 I)$.

- Serum fatty acid esters (Table 3) Patients taking alprenolol had significantly higher levels at 3 months $(P<0.01)$, but the difference was no longer significant at I year because of a rise in the patients on placebo and a fall in those taking alprenolol.

- (b) Exercise studies Heart rate A highly significant difference in heart rate between the control and treatment groups was found both on their normal treatment and alternative treatment at all levels of exercise. The difference was significant at rest, became highly significant at all levels of exercise, and was - highly significant when comparing the heart rate over the 5-minute recovery period (Tables
TABLE 3 Details on trial patients

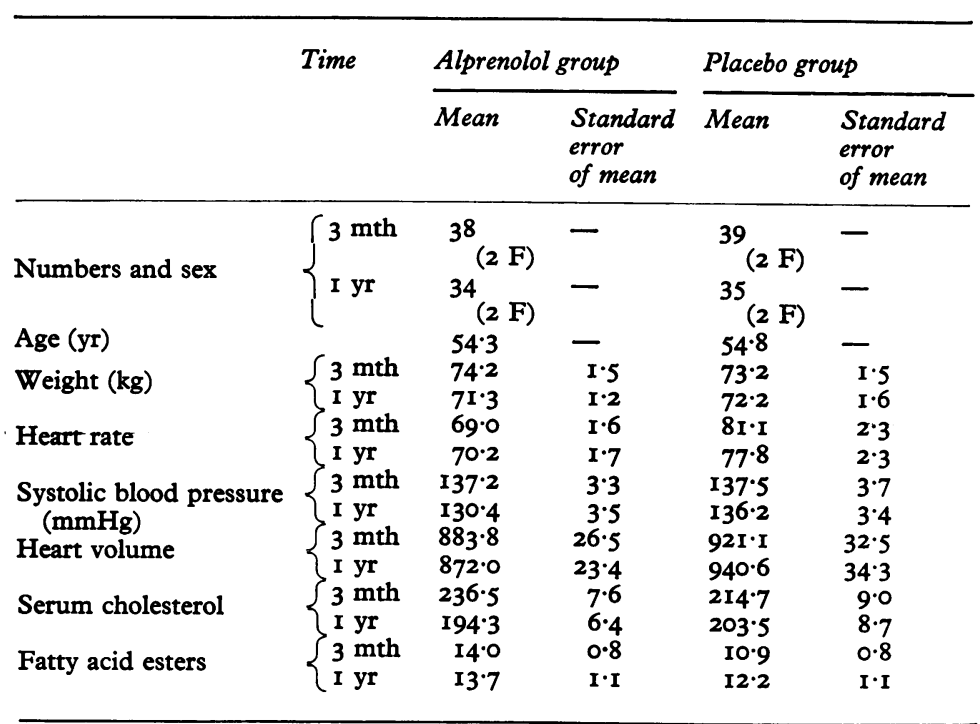

5 and 6). The difference was more obvious between two studies in the control group than between those in the treatment group, and this is probably a reflection of a carry-over effect in the alprenolol group stopping treatment and being tested while taking the placebo I8 to 24 hours later (Fig.).

Blood pressure There was a highly significant drop in resting systolic blood pressure when the control group took alprenolol for the day of the exercise, but the rise in blood pressure when the treatment group stopped treatment for 18 to 24 hours was not significant, again probably due to a carry-over effect. However, there was a highly significant difference in systolic pressure at maximum exercise both within the groups and between the groups (Tables 5 and 6). The blood pressure after 5 minutes of recovery showed similar differences to those found at rest.

TABLE 4 Details of patients in exercise studies

\begin{tabular}{|c|c|c|c|c|}
\hline \multirow[t]{2}{*}{ Parameter } & \multicolumn{2}{|c|}{ Alprenolol group } & \multicolumn{2}{|c|}{ Placebo group } \\
\hline & Mean & $\begin{array}{l}\text { Standard } \\
\text { error } \\
\text { of mean }\end{array}$ & Mean & $\begin{array}{l}\text { Standard } \\
\text { error } \\
\text { of mean }\end{array}$ \\
\hline $\begin{array}{l}\text { Number } \\
\text { Age } \\
\text { Weight (kg) } \\
\text { Height (cm) }\end{array}$ & $\begin{array}{c}15 \\
53 \cdot 5 \\
70 \cdot 6 \\
172 \cdot 1\end{array}$ & $\begin{array}{l}- \\
2 \cdot 4 \\
1 \cdot 5 \\
1 \cdot 6\end{array}$ & $\begin{array}{l}15 \\
51 \cdot 4 \\
74 \cdot 7 \\
173 \cdot 9\end{array}$ & $\begin{array}{l}-1 \cdot 9 \\
2 \cdot 6 \\
2 \cdot 0\end{array}$ \\
\hline
\end{tabular}


Occurrence of ectopic beats More of the control group had ectopic beats, both at rest and on exercise, and on placebo or alprenolol, than the alprenolol group (Tables 5 and 6). This difference, and the difference in frequency of ectopic beats, was not statistically significant, due to the fairly low incidence and large variation in the number of ectopic beats in those patients affected.

Angina pectoris There was a lower incidence, statistically insignificant, of angina pectoris during exercise in all subjects when they received alprenolol. The incidence was also lower overall in the group who had been taking alprenolol over 8 to 12 months.

Ischaemic changes in electrocardiogram There was no difference in incidence of ST changes in the electrocardiogram. Those patients who developed electrocardiographic changes did so on both alprenolol and placebo, and the occurrence of these changes did not correlate with the incidence of angina pectoris.

Spirometry Spirometry (vital capacity and $\mathrm{FEV}_{1}$ ) was measured on each patient before the studies to determine any measurable bronchoconstriction, but there was no difference between the groups (Tables 5 and 6).

Ventilation There was no significant difference between the groups at rest, though ventilation was a little lower when the subject was taking alprenolol. This trend was more obvious on exercise (Tables 5 and 6). This was shown in the results which had been corrected for weight, but the same differences were more conspicuous in the uncorrected data. Again the difference in the control group on and off alprenolol was more obvious than in the treatment group and was significantly different $(P<0.025)$.

Respiratory frequency There was no difference either at rest or on exercise (Tables 5 and 6).

Oxygen uptake The oxygen uptake at rest was significantly lower (by $12.9 \%$ ) in the treatment group receiving alprenolol than in the control group receiving placebo $(\mathrm{P}<0.05)$. The difference in mean weight $(5.5 \%)$ is unlikely to account for the whole difference at rest. On exercise there was a difference in the same direction, but this was significant $(P<0.05)$ only within the placebo group compared on and off alprenolol (Tables 5 and 6).
TABLE 5 Results of exercise studies

\begin{tabular}{|c|c|c|c|c|c|}
\hline \multirow[t]{2}{*}{ Parameters } & & \multicolumn{2}{|c|}{$\begin{array}{l}\text { Alprenolol studies of } \\
\text { I } 5 \text { patients on long- } \\
\text { term alprenolol }\end{array}$} & \multicolumn{2}{|c|}{$\begin{array}{l}\text { Placebo studies of I5 } \\
\text { patients on long-term } \\
\text { placebo }\end{array}$} \\
\hline & & Mean & $\begin{array}{l}\text { Standard } \\
\text { error } \\
\text { of mean }\end{array}$ & Mean & $\begin{array}{l}\text { Standard } \\
\text { error } \\
\text { of mean }\end{array}$ \\
\hline \multirow{6}{*}{ Heart rate (beats/min) } & Rest & $69 \cdot 4$ & $2 \cdot 2$ & $75 \cdot 5$ & $2 \cdot 0$ \\
\hline & $4 \%$ & $99 \cdot 0$ & $2 \cdot 7$ & 112.9 & $3 \cdot 6$ \\
\hline & $\begin{array}{r}8 \% \\
16 \%\end{array}$ & $\begin{array}{l}105.3 \\
118.9\end{array}$ & $\begin{array}{l}2 \cdot 5 \\
2 \cdot 4\end{array}$ & $\begin{array}{l}121 \cdot 4 \\
140 \cdot 8\end{array}$ & $\begin{array}{l}3 \cdot 8 \\
3 \cdot 8\end{array}$ \\
\hline & Recovery & $83 \cdot 7$ & $3 \cdot \mathbf{I}$ & 103.7 & 3.4 \\
\hline & Rest & $8 \cdot 6$ & 0.4 & 10.2 & 0.6 \\
\hline & $4 \%$ & $21 \cdot 7$ & 0.9 & $23 \cdot 8$ & $I \cdot O$ \\
\hline \multirow[t]{5}{*}{ Ventilation (1./min) } & $8 \%$ & $26 \cdot 4$ & 0.9 & $29 \cdot 2$ & $\mathbf{I} \cdot \mathbf{I}$ \\
\hline & $16 \%$ & $38 \cdot 5$ & $I \cdot 6$ & $4 I \cdot 7$ & I.7 \\
\hline & Recovery & 18.4 & 0.9 & $20 \cdot 9$ & $I \cdot 2$ \\
\hline & Rest & $24 I \cdot 0$ & $10 \cdot 7$ & $276 \cdot 6$ & $8 \cdot 5$ \\
\hline & $4 \%$ & $976 \cdot 0$ & $5 I \cdot I$ & $993 \cdot I$ & $39 \cdot 4$ \\
\hline \multirow{4}{*}{$\begin{array}{l}\text { Oxygen uptake } \\
(\mathrm{ml} / \mathrm{min})\end{array}$} & $8 \%$ & $1073 \cdot 2$ & $38 \cdot 1$ & II $77 \cdot 3$ & $35 \cdot 7$ \\
\hline & $16 \%$ & $\begin{array}{r}1360 \cdot 8 \\
518.6\end{array}$ & $56 \cdot 4$ & $1491 \cdot 3$ & 44.4 \\
\hline & $\begin{array}{l}\text { Recovery } \\
\text { Rest }\end{array}$ & $\begin{array}{r}518.6 \\
15.8\end{array}$ & $\begin{array}{r}16 \cdot 4 \\
T \cdot T\end{array}$ & $546 \cdot 2$ & 19.4 \\
\hline & $4 \%$ & $\begin{array}{l}150 \\
17 \cdot 3\end{array}$ & $\begin{array}{l}I \cdot I \\
0.9\end{array}$ & $\begin{array}{l}15.1 \\
10.2\end{array}$ & 0.7 \\
\hline \multirow{5}{*}{$\begin{array}{l}\text { Respiratory frequency } \\
\text { (breaths/min) }\end{array}$} & $8 \%$ & 19.9 & $\begin{aligned} 1.0 \\
10\end{aligned}$ & $\begin{array}{l}19 \cdot 3 \\
20 \cdot 1\end{array}$ & 0.0 \\
\hline & $16 \%$ & $23 \cdot 7$ & $I \cdot I$ & $\begin{array}{l}20.1 \\
25.5\end{array}$ & $\begin{array}{l}0.7 \\
1 \cdot 0\end{array}$ \\
\hline & Recovery & 18.9 & $I \cdot I$ & 19.9 & $\mathbf{I} \cdot \mathbf{2}$ \\
\hline & Rest & 0.905 & 0.022 & 0.873 & 0.030 \\
\hline & $4 \%$ & 0.776 & 0.014 & 0.796 & 0.014 \\
\hline \multirow[t]{4}{*}{ Respiratory quotient } & $8 \%$ & 0.878 & 0.010 & 0.857 & 0.010 \\
\hline & $16 \%$ & 0.997 & 0.014 & 0.971 & 0.001 \\
\hline & Recovery & $I \cdot 105$ & 0.028 & I.09I & 0.028 \\
\hline & Rest & $127 \cdot 9$ & $4 \cdot 3$ & $138 \cdot 1$ & 4.9 \\
\hline \multirow{3}{*}{$\begin{array}{l}\text { Systolic blood pressure } \\
\text { (mmHg) }\end{array}$} & Exercise & 142.9 & $6 \cdot 8$ & I74.4 & $6 \cdot 3$ \\
\hline & Recovery & $132 \cdot 4$ & $5 \cdot 7$ & $146 \cdot 4$ & $3 \cdot 1$ \\
\hline & Rest & 0.02 & 0.02 & 0.86 & 0.79 \\
\hline \multirow{3}{*}{$\begin{array}{l}\text { Frequency of ectopic } \\
\text { beats/min }\end{array}$} & Exercise & 0.39 & 0.17 & $2 \cdot 15$ & $1 \cdot 22$ \\
\hline & Recovery & 0.49 & 0.26 & $I \cdot 84$ & I.OI \\
\hline & VC & 3611 & 144 & 3863 & I7I \\
\hline \multirow[t]{2}{*}{ Spirometry } & $\mathrm{FEV}_{1}$ & 2951 & I6I & 2981 & 219 \\
\hline & Ratio & $8 r \cdot 4$ & $2 \cdot 0$ & $75 \cdot 4$ & $3 \cdot 0$ \\
\hline
\end{tabular}

Respiratory quotient There was no obvious difference in RQ either at rest or on exercise (Tables 5 and 6).

\section{Discussion}

Alprenolol, like propranolol, has a direct depressant action on myocardial contractility, but, unlike propranolol, this effect usually occurs at dose levels considerably in excess of that necessary for $\beta$-blockade (Ablad et al., 1967). In the patients taking alprenolol either the depressant effect or the removal of sympathetic stimulation of the myocardium might be expected to result in exertional dyspnoea or overt cardiac failure more frequently than in similar patients receiving placebo. In this trial, the incidence of these events was not significantly different in the two groups (Tables I and 2). After one year there was 


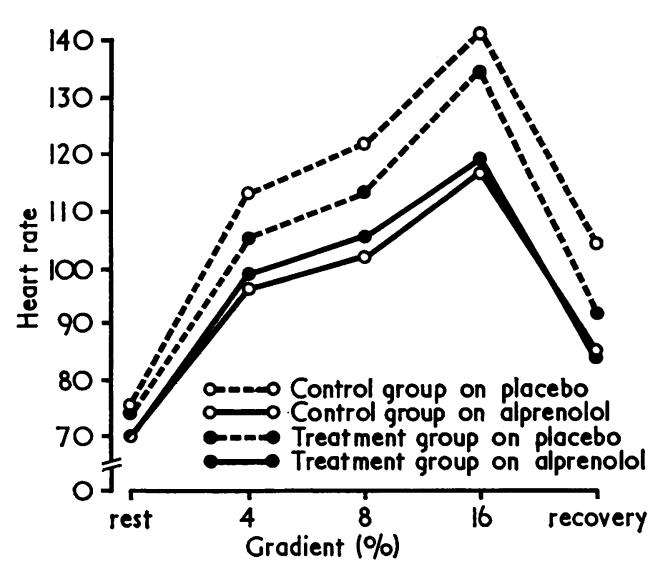

FIG. Heart rate during rest, exercise, and recovery.

also no evidence of an injurious effect on the myocardium as gauged from the heart volume measurements (Table 3) which show no significant difference between the alprenolol and placebo groups and no significant change in the alprenolol groups between 3 months and I year.

The incidence of angina pectoris at the end of I year was apparently greater in the patients taking alprenolol (Table 2) but not significantly so. However, this finding is not supported by the figures on trinitrin consumption (Table 2 ) and is also the converse of the findings during the exercise studies. It could be inferred from this that interrogation of patients at routine visits is not a reliable guide to the true incidence of angina of effort especially when compared with interrogation directly after the completion of a set level of exercise.

Most investigators (Wolfson and Gorlin, I969; Craven and Pitt, I968; McKenna et al., I966) who have studied the effects of $\beta$ blockade on coronary blood flow have interpreted their results to mean that $\beta$-blockers may cause coronary vasoconstriction. It is possible however that this effect is outweighed by the advantages of the reduction in cardiac work, and therefore myocardial oxygen consumption produced by the $\beta$-blockade or other mechanisms (Parratt and Wadsworth, - 1969).

The numbers of patients taking trinitrin in the two groups were similar (Table 2) but fewer trinitrin tablets were consumed by the patients on alprenolol (Table 2). The difference is not statistically significant but is influenced by the large variance in trinitrin - consumption.

A fall in the resting systolic blood pressure
TABLE 6 Results of exercise studies

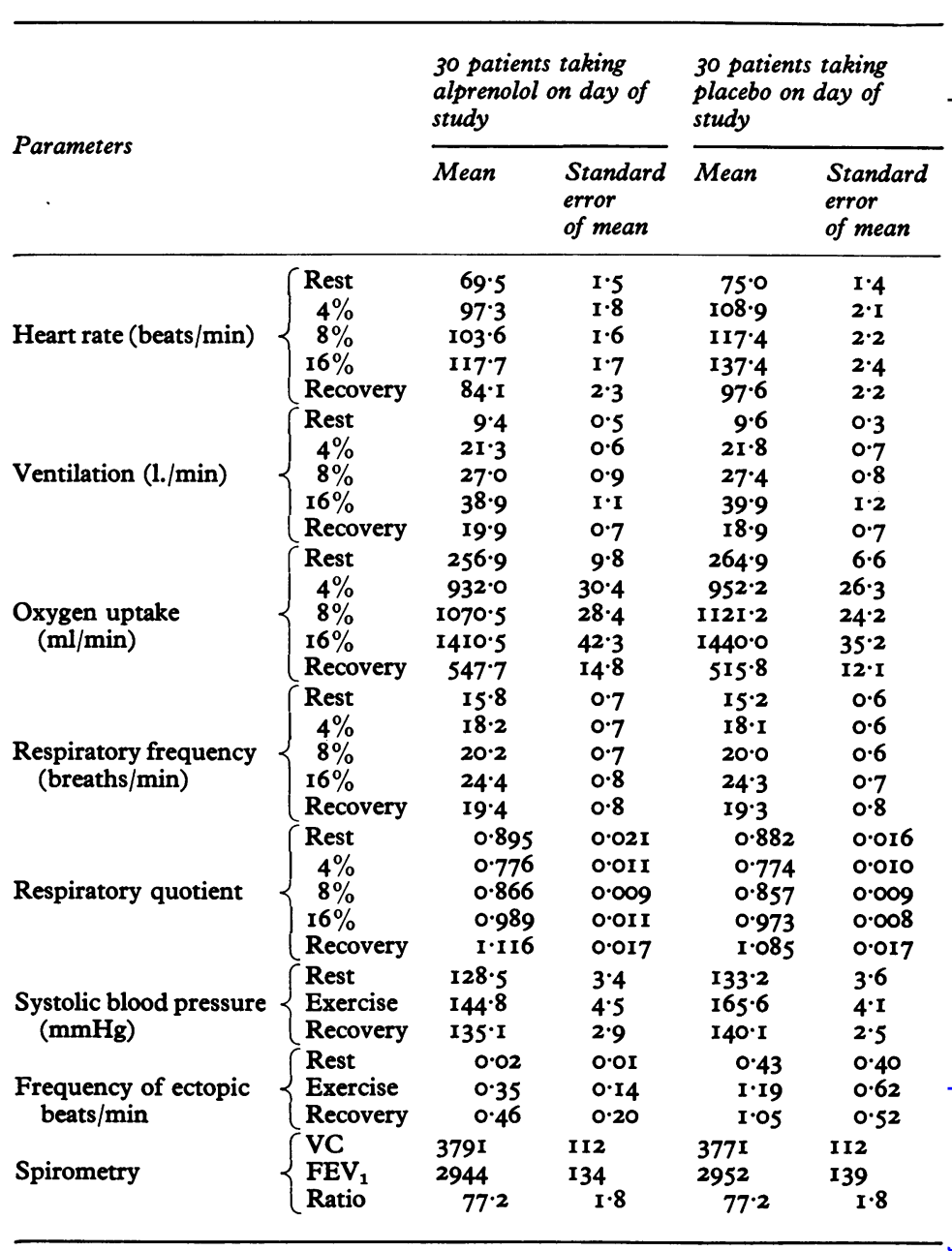

in the period 3 months to I year occurred in the patients taking alprenolol (Table 3). A comparable fall in blood pressure has been observed by Arstila, Iisalo, and Kallio (1969) in a clinical trial of alprenolol in angina pectoris. This gradual fall in blood pressure over a long period has been observed by others Prichard and Gillam (1966). It has been stated that the rate of atherogenesis is directly related to the blood pressure, and that lowering the blood pressure favourably affects the incidence of some of the complications of atherosclerosis in man (Deming, 1968). The observed fall in blood pressure may therefore favourably affect the course of ischaemic heart disease. The systolic blood pressure during the exercise studies was also lower when the subject was on alprenolol (Tables 5 and 6). This, coupled with the lower heart rate (Tables 5 and 6), resulted in reduced cardiac 
work at similar loads of external body work when compared with subjects on placebo. The lower systolic blood pressure during exercise may reflect a change in myocardial contractility. Exercise during $\beta$-blockade with propranolol has been shown to cause a fall in mechanical efficiency of the heart, indicating a change in myocardial contractility (Wolfson and Gorlin, 1969; Sowton and Hamer, 1966). In our exercise studies, no patient during $\beta$ blockade was objectively dyspnoeic, but three complained of breathlessness. Two patients receiving placebo complained of breathlessness. Since the level of cardiac work is lower during exercise when associated with $\beta$-blockade it seems likely, in patients taking alprenolol, that daily activities would make a smaller demand on the impoverished $\mathrm{O}_{2}$ reserve capacity of the coronary circulation, and there would be fewer occasions when myocardial anoxia, and the risks that attend it, arise. This was not supported by the present exercise studies which failed to show a significant reduction in the incidence of anginal pain, ventricular premature beats (Tables 5 and 6 ), or ischaemic changes in the electrocardiogram in subjects taking alprenolol. However, most patients who noticed a difference in their sensations during exercise expressed a preference in favour of alprenolol.

The change in heart rate and blood pressure on and off treatment, which was found during the exercise studies, would be expected with alprenolol and confirms that the dosage was adequate. However the differences were more conspicuous within the placebo group than within the alprenolol group. This could be due to three factors: (i) development of tolerance in the group who had been taking alprenolol for a year, making the same dosage less effective; (ii) a training effect that would cause a better performance on the second run; in the three patients who had more than two exercise studies for various reasons there was no significant improvement; (iii) a carry-over effect because the treatment had been stopped for an insufficient period (I 8-24 hours) before the control study was made. The latter seems most likely, especially in view of the similarity of the heart rates obtained on alprenolol in both groups and the differences in heart rate on placebo. This is shown well in the Fig.

The difference in ventilation (lower on alprenolol) is most likely due to the metabolic differences described in treatment with $\beta$ blockers. This is also reflected in the lower oxygen uptake on treatment. The alternative explanation of a mechanical change due to bronchoconstriction is not tenable because it would tend to accentuate any existing dis- tribution problem, and therefore cause a higher ventilation, and would usually be associated with a change in respiratory frequency which was not demonstrated. Though a change in resting or exercise respiratory quotient might be expected if metabolism is altered, none was seen (Tables 5 and 6).

The fall in weight of patients taking alprenolol over a long period could possibly be due to an appetite suppressant effect. Most of the patients noted an improvement in appetite after stopping the drug at the end of a year.

We are indebted to Dr. J. K. McMyn (Senior Radiologist at Green Lane Hospital) who carried out the radiological assessment of heart volume. Messrs Astra Pharmaceuticals Ltd. generously provided supplies of alprenolol and placebo and donated the Servomex paramagnetic oxygen analyser. The authors are grateful for the skilled technical assistance of Mrs. M. Vedder, A.S.C.T., supported by the Auckland Medical Research Foundation.

\section{References}

Ablad, B., Brogard, M., and Ek, L. (1967). Pharmacological properties of $\mathrm{H}_{5} 6 / 28$ - a beta adrenergic receptor antagonist. Acta Pharmacologica et Toxicologica, Suppl. 2, 9.

Arstila, M., Iisalo, E., and Kallio, V. (I969). Alprenolol in angina pectoris. Annals of Clinical Research, $\mathbf{r}$, I3.

Briant, R. B., and Norris, R. M. (1970). Aprenolol in acute myocardial infarction: double-blind trial. New Zealand Medical fournal, 71, 135.

Cooley, R. N., and Schreiber, M. H. (I967). Radiology of the Heart and Great Vessels. Williams and Wilkins, Baltimore.

Craven, P., and Pitt, B. (1968). Effect of propranolol on regional myocardial blood flow in acute ischemia. Circulation, Suppl. 6, 61.

Deming, Q. B. (1968). Blood pressure: its relation to atherosclerotic disease of the coronaries. Bulletin of the New York Academy of Medicine, 44, 968.

Denborough, M. A., Lovell, R. R. H., Nestel, P. J., and Goble, A. J. (1968). Arrhythmias and late sudden death after myocardial infarction. Lancet, $\mathbf{r}$, 386.

Domenet, J. G., Evans, D. W., and Howarth, F. H. (1963). Clinical experience with radiological determination of heart volume. British Heart fournal, 25, 575.

Gertler, M. M., Driskell, M. M., Bland, E. F., Garn, S. M., Lerman, J., Levine, S. A., Sprague, H. B., and White, P. D. (195I). Clinical aspects of coronary heart disease. fournal of the American Medical Association, 146, 1291.

Gillam, P. M. S., and Prichard, B. N. C. (1965). Use of propranolol in angina pectoris. British Medical fournal, 2, 337.

Hickie, J. B. Bernstein, L., Cutforth, R., Donnelly, G. L., Hetzel, P., McCredie, J. M., Morgan, J., Neilsen, G., Pitts, A., and Seldon, W. A. (I970). Alprenolol in angina pectoris - a double blind multicentre trial. Australasian Annals of Medicine, 19, 190. 
McKenna, D. H., Corliss, R. J., Sialer, S., Zarnstorff, W. C., Crumpton, C. W., and Rowe, G. C. (1966). Effect of propranolol on systemic and coronary haemodynamics at rest and during simulated exercise. Circulation Research, 19, 520.

Norris, R. M., Caughey, D. E., and Scott, P. J. (1968). Trial of propranolol in acute myocardial infarction. British Medical fournal, 2, 398.

Parratt, J. R., and Wadsworth, R. M. (1969). Myocardial and haemodynamic effects of the $\beta$-adrenoreceptor blocking drug alprenolol in anaesthetised cats. British Fournal of Pharmacology, 37, 357.

Prichard, B. N. C., and Gillam, P. M. S. (1966). Propranolol in hypertension. American fournal of Cardiology, 18, 387.

Snow, P. J. D. (1965). Effects of propranolol in myocardial infarction. Lancet, 2, $55 \mathrm{I}$.

Sowton, E., and Hamer, J. (I966). Hemodynamic changes after beta-adrenergic blockade. American Fournal of Cardiology, 18, 317.
Weiss, A. N., Jobe, C. L., Gordon, T., Lange, P. H., and Frommer, P. L. (1969). Relationship of premature ventricular contractions and left ventricular hypertrophy to sudden cardiac death. Circulation, Suppl. 3, 213.

Wolfson, S., and Gorlin, R. (1969). Cardiovascular pharmacology of propranolol in man. Circulation, 40, 501 .

Wolfson, S., Heinle, R. A., Herman, M. V., Kemp, H. G., Sullivan, J. M., and Gorlin, R. (1966). Propranolol and angina pectoris. American fournal of Cardiology, 18, 345.

Yater, W. M., Traum, A. H., Brown, W. G., Fitzgerald, R. P., Geisler, M. A., and Wilcox, B. B. (1948). Coronary artery disease in men 18 to 39 years of age. American Heart fournal, 36, 334.

Requests for reprints to Dr J. L. Reynolds, Green Lane Hospital, Green Lane West, Auckland 3, New Zealand. 